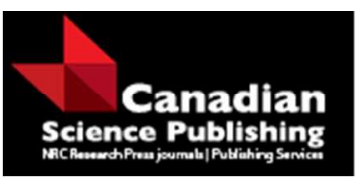

Canadian Journal of Forest Research Revue canadienne de recherche forestière

\title{
Ground layer composition affects tree fine root biomass and soil nutrient availability in jack pine and black spruce forests under extreme drainage conditions
}

\begin{tabular}{|c|c|}
\hline Journal: & Canadian Journal of Forest Research \\
\hline Manuscript ID & cjfr-2016-0352.R1 \\
\hline Manuscript Type: & Article \\
\hline Date Submitted by the Author: & 29-Nov-2016 \\
\hline Complete List of Authors: & $\begin{array}{l}\text { Pacé, Marine; Université du Québec en Abitibi-Témiscamingue - Campus de } \\
\text { Rouyn-Noranda, Institut de recherche sur les forêts; Centre de foresterie } \\
\text { des Laurentides, } \\
\text { Fenton, Nicole; Universit du Qu bec en Abitibi-T miscamingue, } \\
\text { Paré, David; Centre de foresterie des Laurentides } \\
\text { Bergeron, Yves; Universit du Qu bec en Abitibi-T miscamingue }\end{array}$ \\
\hline Keyword: & lichen, moss, Sphagnum spp., fine root, forest regeneration \\
\hline
\end{tabular}

\section{SCHOLARONE \\ Manuscripts}


1 Ground layer composition affects tree fine root biomass and soil nutrient availability in jack pine and black spruce forests under extreme drainage conditions

4 Marine Pacé ${ }^{1,2}$, Nicole J. Fenton ${ }^{1}$, David Paré ${ }^{2}$ and Yves Bergeron ${ }^{1}$.

$5{ }^{1}$ Forest Research Institute, Université du Québec en Abitibi-Témiscamingue, 445 boul. de

6 l’Université, Rouyn-Noranda, QC J9X 5E4, Canada.

$7 \quad{ }^{2}$ Laurentian Forestry Centre, Canadian Forest Service, 1055 du P.E.P.S., Québec, QC G1V 4C7, 8 Canada.

9

10 Corresponding author:

11 Marine Pacé

12 (email: marine.pace@uqat.ca)

14 Other authors:

15 Nicole J. Fenton: nicole.fenton@uqat.ca

16 David Paré: david.pare@canada.ca

17 Yves Bergeron: yves.bergeron@uqat.ca 
18 Abstract: In the boreal forest, long-lasting canopy gaps are associated with lichens on dry sites

19 and with Sphagnum spp. on wet sites. We hypothesize that ground layer composition plays a role

20 in maintaining gaps through its effects on fine root biomass $(\varnothing \leq 2 \mathrm{~mm})$ and soil nutrient

21 availability. Along gradients of canopy openness in both jack pine-lichen and black spruce-moss

22 forests, the relationships between canopy closure, ground layer composition, tree fine root

23 biomass and soil nutrients were analyzed and decomposed using path analysis. The effects of

24 lichen and Sphagnum spp. removal on tree fine root biomass and soil nutrients were tested in situ.

25 Although variations in pine fine root biomass were mainly explained by stand aboveground

26 biomass, lichen removal locally increased fine root biomass by more than $50 \%$, resin extractable

27 soil potassium by $580 \%$ and base cations by $180 \%$. While Sphagnum cover was identified as a

28 key driver of stand aboveground biomass reduction in paludified forest sites, its removal had no

29 short-term effects on spruce fine root biomass and soil nutrients. Our results suggest that lichens,

30 unlike Sphagnum spp., affect tree growth via direct effects on soil nutrients. These two different

31 patterns call for different silvicultural solutions to maintain productive stands.

32 Key words: lichen, moss, Sphagnum spp., fine root, forest regeneration. 
33 Résumé : En forêt boréale, l'ouverture prolongée du couvert forestier favorise un couvert de

34 lichens sur les sites xériques et à un couvert de sphaignes sur les sites hydriques à subhydriques.

35 Nous faisons l'hypothèse que la composition de la strate des mousses et lichens joue un rôle dans

36 le maintien de clairières ouvertes en affectant la biomasse racinaire fine $(\varnothing \leq 2 \mathrm{~mm})$ et la

37 disponibilité en nutriments dans le sol. Le long de gradients d'ouverture du couvert en pinède à

38 lichens et en pessière à mousses, les relations entre l'ouverture de la canopée, la composition de

39 la strate des mousses et lichens, la biomasse de racines fines des arbres et les nutriments du sol

40 ont été analysées et décomposées en suivant une analyse de pistes. Ces observations ont été

41 complétées par une expérience in situ visant à mesurer les effets de la suppression du lichen et de

42 la sphaigne sur la biomasse racinaire fine des arbres et sur le contenu en nutriments du sol. Bien

43 que les variations de la biomasse de racines fines des pins soient principalement expliquées par

44 les caractéristiques aériennes du peuplement, la suppression du lichen a localement augmenté la

45 biomasse de racines fines de plus de $50 \%$, ainsi que la disponibilité en potassium et en cations

46 basiques extraits de résine de $580 \%$ et $180 \%$ respectivement. Alors que le couvert en sphaignes

47 est identifié comme un facteur clé de la réduction de biomasse aérienne des épinettes dans les

48 sites paludifiés, la suppression de la sphaigne n'a pas directement affecté la biomasse des racines

49 fines d'épinettes et le contenu en nutriments du sol. Ces résultats suggèrent que le lichen, à la

50 différence de la sphaigne, affecte la croissance des arbres en modifiant les conditions nutritives

51 du sol. Le maintien de peuplements forestiers productifs sur ces deux types de site nécessite des

52 aménagements sylvicoles différents.

53 Mots-clés : lichen, mousse, sphaigne, racines fines, régénération forestière. 


\section{Introduction}

55 The ground layer (i.e. bryophyte and lichen layer) is an important component of the boreal forest

56 biome (Cornelissen et al. 2007), whose composition largely influences ecosystem processes,

57 including the carbon cycle via differential rates of primary production (Turetsky 2003) and

58 decomposition (Lang et al. 2009), and the nitrogen cycle via differential rates of atmospheric

59 nitrogen fixation (DeLuca et al. 2002) or nitrogen immobilization (Augusto et al. 2015). It also

60 influences soil processes through the modification of drivers such as $\mathrm{pH}$, temperature,

61 oxygenation and moisture regime (Fenton et al. 2006). Moss and lichen species affect microbial

62 and fungal community composition (Ohtonen and Väre 1998; Sedia and Ehrenfeld 2003), either

63 indirectly through their effects on soil conditions (Nilsson and Wardle 2005) or directly through

64 allelochemical emission (Molnar and Farkas 2010; Chiapusio et al. 2013), although this second

65 pathway remains highly controversial (Kytöviita et al. 2009).

66 The influence of the ground layer on ecosystem functions in the boreal forest may have visible

67 consequences at the stand scale. Under some conditions, a forest can move from a productive

68 state to an alternative state that is commercially unproductive (i.e., lichen woodland or forested

69 peatland). These conditions of openness are maintained by deficits in tree regeneration and/or

70 growth. They tend to occur on sites with extreme drainage conditions, i.e., either rapidly drained

71 sites on coarse-grained deposits (Jasinski and Payette 2005) or poorly drained sites subject to

72 paludification (Simard et al. 2007). In both cases, long-term forest stand opening is associated

73 with a shift in the composition of the ground layer. Feather mosses are replaced by lichens on

74 rapidly drained sites (Payette et al. 2000) and by Sphagnum spp. mosses on poorly drained sites

75 (Bisbee et al. 2001) since the two are favoured by the increase in light availability. Since mosses

76 and lichens have different effects on the physical, chemical and biological conditions of the forest 
77 soil, ground layer compositional changes may have consequences on tree regeneration and/or

78 growth. For example, it has been demonstrated that seedling growth is greater in feather mosses

79 than in Sphagnum spp. (Lafleur et al. 2011), and that some secondary metabolites produced by

80 lichens (e.g., usnic acid) may have allelopathic effects on microorganisms, fungi, and trees (Sedia

81 and Ehrenfeld 2003; Molnar and Farkas 2010). As the ground layer may affect tree growth

82 through its effects on roots, we used fine root biomass as an indicator of the impact of the ground

83 layer on tree physiology.

84 While aboveground forest processes have been relatively well studied, belowground processes

85 remain poorly understood (Augusto et al. 2015). Trees adapt to belowground conditions and

86 resource availability by changes in biomass allocation between above- and belowground organs

87 (Brassard et al. 2009; Noguchi et al. 2012), root branching pattern and longevity (Persson and

88 Ahlström 2002) and mycorrhizae colonization (Kalliokoski et al. 2010). Tree fine root biomass

89 constitutes an easily measurable indicator of tree adaptation in contrasted environments. Indeed,

90 fine roots are particularly important for nutrient and water uptake (Brassard et al. 2009) as they

91 offer a maximized exchange area (Taskinen et al. 2003), in part through their association with

92 symbiotic mycorrhizae (Hinsinger et al. 2009). Moreover, fine roots have a relatively short

93 lifespan and adapt quickly to changes in soil conditions or water supply (Persson and Ahlström

94 2002).

95 In this study, we focus on the effects of ground layer composition on tree fine root biomass as an

96 indicator of tree physiology adjustment, and the way these effects interact with the shading effect

97 of forest cover. This approach is innovative for several reasons: firstly, we consider two types of

98 sites that are very different a priori, but that are undergoing similar processes; secondly, we focus

99 on the ground layer whose role in forest ecosystem processes is poorly appreciated; finally, we

100 examine fine root biomass while previous research on long-term canopy opening has focused on 
101 aboveground tree growth (Gower et al. 1996; Fauria et al. 2008). We hypothesize that lichen and

102 Sphagnum spp. covers, which are favored by the absence of shading effect from the forest cover,

103 contribute to maintaining stand openness by inhibiting tree fine root development and

104 maintaining a low soil nutrient availability. Based on both observational and experimental

105 approaches, the objectives of this study are: (i) to determine the relationships between ground cover

106 composition, tree fine root biomass, canopy closure and soil nutrient availability in forests that

107 include the two stable states, i.e., open- and closed-crown stands; and (ii) to determine the effects

108 of lichen and Sphagnum spp. removal on tree fine root biomass and soil nutrient availability as

109 well as the way these effects are modified by shade and fertilization in open-crown forests. The

110 first approach allows us establishing general correlation patterns of tree fine root biomass at the stand

111 scale, while the second provides experimental support and a better understanding of the drivers

112 responsible for the correlation patterns we observe.

\section{Material and methods}

\section{Study area}

115 The study area is located in the spruce-moss forest of western Quebec (Table 1). Forest

116 composition is dominated by black spruce (Picea mariana [Mill.] B.S.P.) with variable

117 abundance of jack pines (Pinus banksiana Lamb.) depending on soil conditions. The natural

118 regeneration of these two tree species particularly depends on the occurrence of fires, which

119 constitute the main natural disturbance in the study area (Bergeron et al. 2004). Average annual

120 temperature is $0 \pm 2.9^{\circ} \mathrm{C}$ and average annual precipitation is $909.1 \mathrm{~mm}$ (Joutel, QC; Environment

121 Canada 2010). The territory is relatively flat and covered by organic or well-sorted mineral

122 deposits. Two forest types were selected for this study: pure jack pine-lichen stands located on

123 fluvioglacial coarse-grained deposits and essentially pure black spruce-moss stands situated on 
124 lacustrine clay deposited by the proglacial lake Ojibway (Blouin and Berger 2005). Common

125 understory plant species are Epigaea repens L., Kalmia angustifolia L., Linnaea borealis L., and

126 Vaccinium angustifolium Ait. in pine-lichen stands, and Chamaedaphne calyculata (L.) Moench,

127 Cornus canadensis L., Gaultheria hispidula (L.) Muhl. ex Bigelow, Rhododendron

128 groenlandicum (Oeder) Kron \& Judd, and Vaccinium angustifolium Ait. in spruce-moss stands.

129 Pleurozium schreberi (Brid.) Mitt., Dicranum polysetum Swartz, D. undulatum Schrad. ex Brid.,

130 Polytrichum strictum Brid., Sphagnum capillifolium (Ehrh.) Edw., S. angustifolium (C. Jens. ex

131 Russ.) C. Jens., and S. fuscum (Schimp.) Klinggr. were the most frequent bryophyte species.

132 Terricolous lichens were mainly represented by Cladonia stellaris (Opiz) Pouzar \& Vězda, $C$.

133 rangiferina (L.) F.H. Wigg., and C. mitis Sandst.

\section{Sampling design}

135 In 2014, we sampled 25- to 38- year-old stands of each forest type with variable post-fire or post-

136 lodging density (Table 1). Each forest type was replicated four times using four geographically

137 separate sites (2 to $12 \mathrm{~km}$ apart for the pine-lichen stands, and 1.5 to $6 \mathrm{~km}$ apart for the spruce-

138 moss stands), each containing four to six randomly distributed circular $100 \mathrm{~m}^{2}$ plots (located at

139 least $200 \mathrm{~m}$ apart) with different degrees of forest canopy closure, for a total of 20 plots per forest

140 type. Within each forest type, variations in canopy closure among plots were not related to

141 variations in soil conditions (Table 2).

142 Aboveground characteristics of the plots were sampled in August 2014. In each $100 \mathrm{~m}^{2}$ plot, we

143 surveyed species composition and cover of the ground layer in a central circular $5 \mathrm{~m}^{2}$ subplot.

144 Given the moderate speed of moss and lichen growth (Turetsky 2003; Kytöviita and Crittenden

145 2007), ground cover composition was supposed to be relatively constant through the growing

146 season. Canopy closure was measured by means of fish-eye photos, taken at the centre of the

147 subplot. The photos were analyzed in terms of percentage of pixels attributable to trees (including 
148 trunk, branches and foliage) using Adobe Photoshop Elements software (Adobe Systems, San

149 José, CA). For six plots per forest type, temperature and air humidity close to the ground layer

150 were recorded from June to September 2014 (Table 1) using HOBO ${ }^{2}$ data loggers $\left(\right.$ HOBO ${ }^{\circledR}$

151 U23 PRO V2, Onset Data Loggers, Bourne, MA). All living trees were recorded within the 100

$152 \mathrm{~m}^{2}$ circular plots surrounding each subplot. Trees measuring less than $1.5 \mathrm{~m}$ were classified into

153 three different height classes (less than $0.5 \mathrm{~m}$, between 0.5 and $1 \mathrm{~m}$, between 1 and $1.5 \mathrm{~m}$ ).

154 Diameter at breast height $(\mathrm{DBH})$ was recorded on trees $>1.5 \mathrm{~m}$ tall. Stand age was estimated

155 based on the time since the last disturbance determined from local archives (Bergeron, personal

156 communication), and verified for each site by selecting 12 to 18 dominant trees and counting tree

157 rings based on non-destructive cores (Table 1). Aboveground tree biomass was calculated from

158 DBH using species-specific biomass equations (Ung et al. 2008).

159 Since tree fine roots are mainly located in the top $20 \mathrm{~cm}$ of soil (Kalliokoski et al. 2010),

160 especially in jack pine and black spruce stands (Noguchi et al. 2012), tree fine root abundance

161 was estimated by extracting three cores randomly located within the central circular $5 \mathrm{~m}^{2}$ subplots

162 of each plot. These cores, which were $5 \mathrm{~cm}$ in diameter and $20 \mathrm{~cm}$ deep from the bottom base of

163 the living ground layer, were extracted using an auger in the beginning of September 2014. This

164 date corresponds to the early end of the growing season, i.e. shortly before the seasonal peak of

165 fine root decomposition (Brassard et al. 2009). We supposed that all the roots we found in the

166 cores at this date have been produced under the influence of the ground layer sampled in august

167 2014. Soil cores were transported to the laboratory in a cooler and kept frozen at $-20^{\circ} \mathrm{C}$ until

168 analysis. Each core was examined to discriminate tree roots from roots of other species (mainly

169 Ericaceae), and to separate fine roots $(\leq 2 \mathrm{~mm}$ diameter $)$ from the larger roots $(>2 \mathrm{~mm}$ diameter $)$

170 that were not considered in this study. We harvested one to three root samples of the most

171 common species from the study sites, i.e., jack pine, black spruce, Kalmia spp., Vaccinium spp. 
172 and Rhododendron spp., and used them to develop recognition criteria based on morphological

173 characteristics. Humidified pine fine roots were beige, slightly reddish and their root tips mostly

174 presented a characteristic "Y" shape when mycorrhized. Spruce roots were reddish brown, darker

175 in colour than pine. Ericaceae roots tended to be darker, thinner and less curved than the two tree

176 species roots. Tree fine roots were rinsed with water, sorted (alive $v s$ dead) following the criteria

177 established (Brassard et al. 2011), dried at $65^{\circ} \mathrm{C}$, and weighed. Fine root biomass was expressed

178 in kilograms per unit area $\left(\mathrm{kg} \cdot \mathrm{ha}^{-1}\right)$.

179 Soil content in dissolved inorganic nitrogen (D.I.N.) was measured in each $5 \mathrm{~m}^{2}$ subplot. The

180 organic layer (O or FH) was sampled in both forest types. In spruce-moss stands, the organic

181 layer was separated into surface and deep layers (1 $\mathrm{m}$ deep). Mineral soil was sampled only in the

182 pine-lichen stands (top $20 \mathrm{~cm}$ ). Mineral samples were air-dried and sieved at $2 \mathrm{~mm}$. Organic

183 samples were first sieved at $6 \mathrm{~mm}$ to remove large roots and debris, dried at $60^{\circ} \mathrm{C}$, then grinded

184 and sieved at $2 \mathrm{~mm}$. $\mathrm{NH}_{4}-\mathrm{N}$ and $\mathrm{NO}_{3}-\mathrm{N}$ were extracted with a $2 \mathrm{M} \mathrm{KCl}$ solution and analyzed by

185 spectrophotometry (QuikChem R8500 Series 2, Lachat Instruments, Milwaukee, WI).

\section{Experimental design}

187 One site per forest type-including a pine-lichen stand and a spruce-Sphagnum spp. stand-was 188 selected in each study area for the experiment (Table 1). For each forest type, $381 \mathrm{~m}^{2}$ circular 189 plots were randomly distributed within the 2 to 4 ha sites so that they contained a homogeneous 190 cover of lichen or Sphagnum spp. The aboveground portion of the Ericaceous plants was clipped

191 off at the soil surface. Ericaceae roots were not removed to avoid ground cover disturbance.

192 Initial tree fine root biomass (expressed in $\left.\mathrm{kg} \cdot \mathrm{ha}^{-1}\right)$ was estimated by extracting two cores $(5 \mathrm{~cm}$ 193 diameter and $20 \mathrm{~cm}$ deep from the bottom base of the living ground layer) per plot at the

194 beginning of the experiment (June 2014) using an auger. Lichens or Sphagnum spp. were then 195 removed on $191 \mathrm{~m}^{2}$ plots while the other 19 were used as controls. Among the 19 plots of each 
196 modality, seven were covered with a $50 \%$ shade cloth (perforated net positioned $20 \mathrm{~cm}$ above the

197 ground surface and covering the whole $1 \mathrm{~m}^{2}$ plot) and 5 were fertilized with $5 \mathrm{~g}$ of controlled-

198 release fertilizer (20\% nitrogen, $7 \%$ phosphorus and $10 \%$ potassium, Plant-Prod Smartcote ${ }^{\circledR}$,

199 Master Plant-Prod Inc., Brampton, ON). Since trees can produce fine roots within a radius of $5 \mathrm{~m}$

200 around the trunk (Taskinen et al. 2003), all trees located within a radius of $5 \mathrm{~m}$ around the $1 \mathrm{~m}^{2}$

201 plots were counted and their DBH was measured. Two other cores per plot were extracted at the

202 end of the experiment (September 2014) to estimate final tree fine root biomass per unit area.

203 June and September cores were stored and analyzed as previously described. For each plot, soil

204 nutrient availability was measured for the duration of the experiment using ion exchange resins

205 buried $10 \mathrm{~cm}$ deep in the soil from June to September 2014. Ion-exchange resin bags (see

206 McCavour et al. 2014) were made using $20 \mathrm{~g}$ of mixed-bed ion-exchange resin (J.T. Baker ${ }^{\circledR}$,

207 Avantor Performance Materials, Central Valley, PA) contained in beige nylon bags (made of

208 standard stockings) and regenerated with $1 M \mathrm{HCl}$. Resins were delicately removed from the soil,

209 kept separately in sealed plastic bags, transported to the laboratory in a cooler, and stored at $4^{\circ} \mathrm{C}$

210 until analysis. $\mathrm{NO}_{3}-\mathrm{N}$ and $\mathrm{NH}_{4}-\mathrm{N}$ were extracted using a $2 M \mathrm{KCl}$ solution and analyzed by

211 spectrophotometry (QuickChem R8500 Series 2, Lachat instruments) to estimate soil D.I.N.

212 Phosphorus, potassium, magnesium, calcium and sodium were extracted using a $2 M \mathrm{HCl}$ solution

213 and analyzed by inductively coupled plasma (ICP) using an optical emission spectrometer (OES)

214 (Optima 7300 DV, Perkin Elmer, Waltham, MA). Soil base cations were estimated by summing

215 the concentrations of the major base cations contained in the resins $(\mathrm{K}, \mathrm{Ca}, \mathrm{Mg}$ and $\mathrm{Na})$.

216 Statistical analyses

217 We considered each forest type separately for statistical analyses. We first used a correlation

218 analysis to examine the relationships between ground cover composition (lichen/Sphagnum spp.

219 cover expressed in \%), tree fine root biomass $\left(\mathrm{kg} \cdot \mathrm{ha}^{-1}\right)$, canopy closure (\%), tree aboveground 
220 biomass (t.ha ${ }^{-1}$ ) and D.I.N. (mg.kg $\left.{ }^{-1}\right)$. A path analysis was then used to discriminate partial 221 correlations between stand aboveground biomass, canopy closure, lichen/Sphagnum spp. cover 222 and tree fine root biomass (Shipley 2002). The use of four variables in the path analysis allowed 223 us to respect the recommendation by Hoagland and Boomstra (1998) advising a limit of eight

224 free parameters for 20 observations for an acceptable performance of the general least squares $\chi^{2}$

225 statistic (Shipley 2002). Path coefficients between these variables made possible the

226 discrimination of direct, non-direct and non-causal correlations. Since our sample was small and

227 may slightly deviate from normality, we used a Yuan Bentler scaled test statistic (Bentler and

228 Yuan 1999) for the d-sep test (Shipley 2002) to determine the likelihood that an a priori structure

229 was correct. Kurtoses were verified for the different variables used in the path analyses (Shipley 230 2002).

231 The relationships between initial tree fine root biomass and stand aboveground biomass in the

232 two experimental sites were first tested to verify if this parameter should be included in the

233 models. The effects of ground cover removal (lichen or Sphagnum spp., according to the forest

234 type) and secondary treatments (shade and fertilization) were then tested on final tree fine root

235 biomass $\left(\mathrm{kg} \cdot \mathrm{ha}^{-1}\right)$ and soil nutrient availability (measured from the ion exchange resins). Linear

236 models were used to decompose the effects of the second factor (secondary treatments) i.e. to

237 analyze the effects of fertilization versus control in a first phase and shade versus control in a

238 second phase. When necessary, the dependent variables of the linear models were transformed to

239 respect normality (log-transformations). When errors were heteroscedastic for one factor

240 (especially for the secondary treatments since variance was higher in fertilized plots than in

241 control and shaded plots), degrees of freedom were sacrificed to estimate the variance associated

242 with each level of factor. All analyses were performed on R-3 software (R Core Team 2014). 


\section{Results}

244 Relationships between stand aboveground biomass, canopy closure, ground cover

245 composition, tree fine root biomass and soil nutrient availability in the sampled area

246 Pine-lichen stands

247 In the pine-lichen stands, variation in stand aboveground biomass was partly related to stand age

248 (Fig.1.a). Feather mosses and lichens varied with canopy closure as expected, with greater lichen

249 cover under open canopies (Fig. 1a; Table 3). Pine fine root biomass, which was $1380 \mathrm{~kg}^{-\mathrm{ha}^{-1}} \mathrm{on}$

250 average (range: 660 to $2060 \mathrm{~kg} \cdot \mathrm{ha}^{-1}$, respectively), was positively associated with stand

251 aboveground biomass and poorly related to lichen cover (Fig.1a; Table 3). Interestingly, pine

252 roots tended to be thinner under lichen than under feather moss (personal observation). Lichen

253 cover tended to be slightly associated with low soil D.I.N. although the trend was not significant

$254(\mathrm{R}=-0.40, p=0.0808)$. The structure determined by path analysis for the pine-lichen stands (Fig.

255 2a) was not rejected by $\mathrm{d}$-sep analysis $(\chi=2.89, \mathrm{df}=2, p$-value $=0.23)$, showing that the data

256 were consistent with the proposed causal structure (Shipley 2002). It indicated that the direct

257 effect of stand aboveground biomass on fine root biomass in the study area was much more

258 important than its indirect effect via canopy closure and lichen cover, and that the slight

259 correlation between lichens and fine root biomass fell more under a non-causal relationship

260 between the two rather than under a direct effect (Fig. 2a; Table 4).

261 Spruce-moss stands

262 The proportion of Sphagnum spp. in the ground layer significantly decreased with the degree of

263 canopy closure in spruce-moss stands (Fig. 1b; Table 3). Tree fine root biomass was higher in

264 spruce-moss stands than in pine-lichen stands with an average of $2810 \mathrm{~kg}$ of spruce fine roots per

265 hectare (range: 310 to $4440 \mathrm{~kg} \cdot \mathrm{ha}^{-1}$ ). Spruce fine root biomass was negatively associated with 
266 Sphagnum spp. cover and poorly related to stand aboveground biomass (Fig.1b; Table 3).

267 Moreover, ground cover composition was closely related to stand aboveground biomass, which

268 decreased significantly with Sphagnum spp. cover (Table 3). Sphagnum spp. cover was not linked

269 to soil D.I.N. Considering the close relationship between Sphagnum spp. cover and stand

270 aboveground biomass, we proposed two causal structures for the path analysis in spruce-moss

271 stands. The first (Fig. 2.b), which is the same as the one proposed for the pine-lichen stands,

272 considers that the Sphagnum spp. cover results from stand aboveground biomass effect on canopy

273 closure. The second considers that Sphagnum spp. cover does not depend on canopy closure, but

274 directly influences stand aboveground biomass, which in turn affects canopy closure. Contrary to

275 the first structure determined by path analysis (Fig. 2b) that was rejected by d-sep analysis $(\chi=$

276 11.48, $\mathrm{df}=2, p$-value $<0.01$ ), the second structure (Fig. 2c) was plausible considering the data $(\chi$

$277=2.77, \mathrm{df}=2, p$-value $=0.11)$. Hence, it suggests that the second causal structure we proposed

278 was a better fit than the first, showing that Sphagnum spp. cover was less a consequence of

279 canopy opening than the main factor explaining low stand aboveground biomass in the sampled

280 area. The two path analyses indicate that tree fine root biomass was more closely related to

281 Sphagnum spp. cover than to stand aboveground biomass (Table 4).

282 Effects of ground cover removal, fertilization and shade on tree fine root biomass and soil

283 properties

284 Pine-lichen forest

285 Initially, there was on average $1070 \mathrm{~kg}$ of pine fine roots per hectare in the pine-lichen plots used

286 for the experimental study (Table 1). Initial pine fine root biomass was poorly associated with

287 stand aboveground biomass in the experimental site (Pearson's $\mathrm{R}=0.14$, t-test statistic $=0.87, p$ -

288 value $>0.1$ ); thus, we did not consider this covariable in the ensuing models. Three months after

289 treatment application, lichen removal on the $1 \mathrm{~m}^{2}$ plots locally increased pine fine root biomass 
290 by more than $50 \%$ (Table 5), rising from $1099 \mathrm{~kg} \cdot \mathrm{ha}^{-1}$ on average for control plots to $1902 \mathrm{~kg} \cdot \mathrm{ha}^{-1}$

291 for plots where ground cover had been removed (Fig. 3). Fertilization and shade did not

292 significantly affect pine fine root biomass (Fig. 3; Table 5).

293 Lichen removal had no effect on D.I.N. and phosphorus, but it positively affected potassium and

294 soil base cations (x 6.8 and x 2.8, respectively), including magnesium (x 2.3) and sodium (x 3.6).

295 Phosphorus, potassium and D.I.N. tended to be higher after fertilization (x 3.1, x 8.8, and x 190,

296 respectively; Fig. 4), although the trend was not significant for phosphorus (Table 5). Soil base

297 cations were also significantly increased by fertilization (more than 3 times higher in fertilized

298 plots compared with control plots). With the exception of phosphorus, the positive effects of

299 fertilization on nutrient availability and base cations were lower in the case of lichen removal

300 (significant negative effect of the interaction between the two treatments; Table 5). Shade

301 reduced the positive effects of lichen removal on potassium and base cations, although it did tend

302 to increase the positive effect of lichen removal on D.I.N. (marginal positive effect of the

303 interaction).

304 Spruce-moss forest

305 Average initial tree fine root biomass in the plots of the spruce-moss experimental site was 1010

$306 \mathrm{~kg}$ of spruce fine roots per hectare (Table 1). As for the pine-lichen site, stand aboveground

307 biomass was poorly associated with the initial spruce fine root biomass in the experimental site

308 (Pearson $\mathrm{R}=0.12$, t-test statistic $=0.71, p$-value $>0.1)$ and was not considered in the ensuing

309 models. Spruce fine root biomass was not affected by Sphagnum spp. removal and shade after 3

310 months. However, it was marginally increased by fertilization $(+42 \%$ on average) (Fig. 3; Table

$3115)$.

312 Sphagnum spp. removal and shade did not affect any of the measured soil nutrient concentrations

313 (Fig. 5; Table 5). However, fertilization strongly affected soil D.I.N., phosphorus and potassium 
314 availability (x 58, x 9.4 and x 3.8, respectively), although it had no effect on base cations.

315 Sphagnum spp. removal increased the positive effect of fertilization on soil D.I.N., but not on 316 phosphorus and potassium.

\section{Discussion}

318 Our results, along with those of previous studies (Fenton and Bergeron 2006; Boudreault et al.

319 2013; Haughian and Burton 2015), indicate that lichens and Sphagnum spp. are more abundant

320 under open canopies than closed ones. The correlation and path analyses indicate that the patterns

321 of variations in tree fine root biomass differ between the two forest types, suggesting that these

322 two ground cover types differ in their influence on soil and tree growth conditions. Since lichens

323 and Sphagnum spp. mosses are mainly associated with open canopies, the close relationship

324 between tree aboveground and fine root biomasses observed in the pine-lichen stands makes the

325 assessment of the direct effect of ground cover composition on fine roots difficult based only on

326 observational data. The experimental manipulation of ground cover in the second part of this

327 study alleviates this problem by neutralizing the confounding effect of tree aboveground

328 characteristics on tree fine root biomass through randomisation of experimental plot location.

329 Given the contrasting patterns observed in the two forest types, lichen and Sphagnum spp. effects

330 on fine roots and soil properties are discussed separately.

\section{Lichen effect on pine fine roots and soil properties}

332 Our estimation of pine fine root biomass was lower than the average values reported by Finér et

333 al. (2007) for Scots pine in the European boreal forest $\left(2290 \pm 1020 \mathrm{~kg} \cdot \mathrm{ha}^{-1}\right)$ and by Yuan and

334 Chen (2010) for pine in the North American and Eurasian boreal forests $\left(2520 \pm 130 \mathrm{~kg} \cdot \mathrm{ha}^{-1}\right)$. By

335 comparing plots with various degrees of canopy closure, we showed that pine fine root biomass

336 per hectare was more closely linked to stand aboveground biomass than it was to lichen cover 
337 (Figs. 1 and 2; Tables 3 and 4). The positive relationship between fine root biomass and stand

338 aboveground biomass in pine-lichen stands of the sampled area suggests that more abundant

339 and/or bigger pines produce more fine roots in the surface soil. This result seems logical as

340 higher aboveground productivity means greater resource needs and, consequently, a larger fine

341 root network to maximize tree resource acquisition. The absence of correlation between initial

342 tree fine root biomass and stand aboveground biomass in the experimental even-aged stand

343 probably results from the higher homogeneity of age and aboveground biomass of the 2 ha

344 experimental site compared with the much larger sampled area.

345 Although the path analysis suggests that there was no direct relationship between lichen cover

346 and pine fine root biomass in the sampled area, this link may have been concealed by the close

347 relationship between tree fine root biomass and stand aboveground characteristics. If we refer to

348 the experimental part of this study, we showed that lichen removal locally increases pine fine root

349 biomass as observed by Fauria et al. (2008) who asserted that lichen grazing positively affects

350 Scots pine growth. This result suggests a negative effect of lichens on tree fine root development

351 as it indicates that pine fine root production may have been stimulated in the short-term by a

352 reduced influence of lichens. We also observed that jack pine roots tend to be thinner under

353 lichens, thus indicating that either pines adapt to the local environment by modifying their fine

354 root structure (Zadworny et al. 2016) or that lichens reduce the quantity of enlarged pine root tips

355 through their negative effects on mycorrhization (Sedia and Ehrenfeld 2003).

356 It has been proposed that lichens modify soil hydric conditions (Bonan and Shugart 1989), as

357 their hydrophobic properties (Shirtcliffe et al. 2006) might contribute to favour dry soils, surface

358 run-off, and heterogeneous horizontal infiltration. Fine root growth can be largely affected by soil

359 moisture (Yuan and Chen 2010) and dry conditions may favour denser tree root networks that

360 optimize prospection and water absorption. Water deficit may also affect soil nutrient transport 
361 and diffusion from the soil to root absorbing surfaces and in this way affect tree access to

362 nutritional resources (Barber et al. 1963). Because it was limited to $1 \mathrm{~m}^{2}$ in our experiment,

363 ground layer removal might have favoured water infiltration and locally stimulated root

364 densification. Therefore, the higher nutrient absorption by the resins when lichens were removed

365 may have been favoured by a greater water flow, while shade cover may have partially mimicked

366 the effects of a lichen mat that limits rain water supply at the surface and thus reduces nutrient

367 transport to the resins.

368 Lichens have been shown to be associated with lower soil nitrogen availability than feather

369 mosses (Ohtonen and Väre 1998). Haughian and Burton (2015) also found a strong negative

370 correlation between lichen cover and phosphorus availability in the forest soil. Lichen removal

371 did not affect D.I.N. and phosphorus concentration in our experimental plots. One possible

372 explanation is that lichen effects on soil nitrogen and phosphorus content are long-lasting and

373 persisted for 3 months after ground layer removal. However, we can point out that lichen removal

374 significantly increased soil potassium and base cations (including calcium, sodium and

375 magnesium), which confirms that lichens also had short-term effects on soil chemical properties.

376 Nutrient availability may be influenced by lichens not only by their low rate of litter

377 accumulation (Sedia and Ehrenfeld 2005), but also through their impact on soil temperature and

378 decomposer activity as they are highly reflective and have low thermal conductivity (Bonan and

379 Shugart 1989). Lichens might also produce antimicrobial and antifungal substances that have

380 negative effects on the activity of soil microbial communities (Sedia and Ehrenfeld 2005) and

381 fungi, including mycorrhizae (Sedia and Ehrenfeld 2003; Molnar and Farkas 2010). Nitrogen

382 mineralization, which should have been stimulated by the positive effect of lichen removal,

383 probably was limited in our experiment by the low availability of decomposable litter in the bare

384 soil plots. 
385 The direction of the correlation between fine root biomass and nutrient availability has been

386 shown to be species-specific (Finér et al. 2007), and relationships in both directions have been

387 found (Persson and Ahlström 2002; Kalliokoski et al. 2010). In the present study, although pine

388 fine root biomass response to fertilization was highly variable and not significant, lichen removal

389 stimulated pine fine root biomass at the same time as it increased soil potassium and base cations.

390 These observations suggest that pines locally produce more fine roots in nutrient-rich spots in a

391 globally low-nutrient forest site. Hence, pines are able to adapt quickly to heterogeneous

392 environments via local stimulation of fine root production in places that are more favourable.

393 Sphagnum spp. effect on spruce fine roots and soil properties

394 Spruce fine root biomass was lower in our study sites than the average values reported by Finér et

395 al. (2007) for Norway spruce in the European boreal forest $\left(3300 \pm 1570 \mathrm{~kg} \cdot \mathrm{ha}^{-1}\right)$ and very close

396 to the average value reported by Yuan and Chen (2010) for spruce in the North American and

397 Eurasian boreal forest $\left(2780 \pm 130 \mathrm{~kg} \cdot \mathrm{ha}^{-1}\right)$.

398 The key biological drivers of forest ecosystem processes can vary with time (forest succession)

399 and space (disturbance history; Nilsson and Wardle 2005). The first structure we proposed for the

400 spruce-moss stands corresponds to a middle-aged forest in which canopy closure is the main

401 biological ecosystem driver. In this theoretical model, stand aboveground biomass affects

402 understorey vegetation through variation in canopy closure. The second considers Sphagnum spp.

403 as the cause instead of the consequence of the variation in stand aboveground biomass. This

404 pattern is more suited to paludified forests where Sphagnum spp. cover and ground layer

405 thickness constitute the most influent ecosystem drivers, more so than forest cover and stand

406 aboveground biomass. Since this second structure best fitted our data, we can deduce that our

407 sites were already quite advanced in the paludification process. The spruce-moss stands we

408 selected for the first part of this study were relatively young and originated from the same fire 
409 (1976). Hence, the paludification we observe today on these sites has probably been favoured by

410 a surface fire that burnt aboveground tree parts without completely removing the organic layer.

411 Spruce fine root growth was not stimulated by Sphagnum spp. removal, but it was stimulated by

412 local fertilization. Hence, we can deduce that the absence of a Sphagnum spp. removal effect on

413 spruce fine root biomass did not result from the lack of spruce reactivity to local environmental

414 changes. Instead, it seems more likely that Sphagnum spp. removal did not sufficiently improve

415 local root growth conditions to have visible consequences on spruce fine root biomass: either

416 Sphagnum spp. effect on soil is long-lasting and continues long after removal, or Sphagnum spp.

417 cover has limited effect on soil properties, at least in the case of a moderately thick moss layer.

418 Another possibility is that the treated surfaces were too small to have significant effect on root

419 growing conditions, given that Sphagnum spp. cover disruption at the stand level has been shown

420 to positively influence soil properties and tree growth (Lafleur et al. 2010). Sphagnum spp. cover

421 was not related to soil D.I.N. and its removal had no effect on soil nutrients. However, Sphagnum

422 spp. removal seemed to increase the positive effect of fertilization on spruce fine root biomass,

423 and significantly increased the fertilization effect on the accumulation of D.I.N. in the forest soil.

424 This suggests that Sphagnum spp. may have immobilized part of the D.I.N. released from

425 fertilizers or that the presence of a ground cover limited nutrient liberation from fertilizer pellets.

426 Management implications

427 Open pine-lichen and spruce-Sphagnum spp. woodlands occur naturally in the boreal forest.

428 Hence, the restoration of forest productivity should not to be systematic and should only be

429 encouraged in managed forests, especially on sites that have been modified by human

430 interventions such as partial or total harvest. Three months of ground layer shading were not

431 sufficient to significantly modify tree fine root biomass and soil properties in both lichen and

432 Sphagnum spp. covers, which confirms that the shading effect of forest cover mainly consists in 
433 an indirect long-term influence on soil through change in ground layer composition. The

434 contrasting effects of lichen and Sphagnum spp. cover on soil properties and tree fine root

435 development indicate that the restoration of forest productivity in pine-lichen and spruce-moss

436 woodlands may require different silvicultural approaches.

437 Lichen cover affects both pine fine root growth and soil nutrients, suggesting that nutrient

438 management may be critical to restore forest productivity in excessively drained sites. Even if

439 lichen removal locally stimulated pine fine root production in our experiment, the effect of lichen

440 disturbance on tree regeneration at a larger scale may differ according to site conditions. Indeed,

441 while Hébert et al. (2006) showed a positive effect of lichen disruption on jack pine growth on

442 sites with good to moderate drainage, other studies suggested that lichen cover favours moisture

443 retention in the surface soil in dry open woodlands and offers more appropriate conditions for

444 jack pine germination and growth than bare soil or feather mosses (Bonan and Shugart 1989;

445 Steijlen et al. 1995). Hence, favouring rapid reforestation that promotes rapid colonization of the

446 understory by feather mosses would be more adapted than ground cover disruption in open dry

447 forests to restore forest productivity in excessively drained sites.

448 Under poor drainage conditions, partial or total harvesting, similarly to low-intensity wildfires

449 and contrary to severe fire disturbances, opens the forest canopy without seriously disturbing the

450 ground layer. In this way, harvesting may favour Sphagnum spp. at the expense of feather

451 mosses. According to our results, Sphagnum spp. removal did not modify fine root development

452 and soil properties. However, path analysis showed that Sphagnum spp. can be the main driver of

453 stand aboveground biomass reduction in paludified forest, indicating that Sphagnum spp. cover

454 becomes very influential late in the paludification process. Indeed, low temperature, low

455 oxygenation and excessive moisture, which are associated with Sphagnum spp. litter

456 accumulation and may not induce particular root adaptations but rather a proportional reduction 
457 in both above- and belowground biomass, may be the most important factors limiting forest

458 productivity (Gower et al. 1996; Fenton et al. 2006). Hence, controlling Sphagnum spp. moss

459 development may be the only key to a successful management of these ecosystems (Thiffault et

460 al. 2013).

\section{Conclusion}

462 In this study, we showed that lichen and Sphagnum spp. covers, which are favoured by conditions

463 of canopy openness, contribute to maintaining stand openness by affecting tree growth conditions

464 in different ways. Lichens affect pine growth conditions by reducing fine root biomass and

465 modifying soil nutrients and major base cations. Sphagnum spp. cover, which was found to be a

466 key driver of spruce biomass reduction on paludified sites, affects black spruce growth through

467 the long-term impact of the accumulation of a thick organic layer on soil physical conditions. The

468 application of a shading cover, as a simulation of forest cover recovery, had no short-term

469 influence on the effects of lichen and Sphagnum spp. on tree fine root growth. In both cases, it

470 appears that managing forest regeneration to accelerate canopy closure and favour feather mosses

471 instead of lichens or Sphagnum spp. mosses may be crucial to restore forest productivity in sites

472 characterized by extreme conditions of drainage.

\section{Acknowledgements}

474 This work was financially supported by the Natural Sciences and Engineering Research Council

475 of Canada, by the Fonds de recherche - Nature et technologie du Québec, and by the Chair in

476 Sustainable Forest Management (NSERC-UQAT-UQAM). We are also grateful to Hugues

477 Massicotte and Sylvie Gauthier for their advice and support, Benjamin Gadet, Florence Auger,

478 Samuel Laflèche, Pauline Suffice, Lili Perreault and Raynald Julien for their help and advice in 
479 the field, Marion Barbé for her support in bryophyte identification, Serge Rousseau for soil

480 analysis, Marie-Hélène Longpré and Danielle Charron for their administrative support, and 481 Isabelle Lamarre for her linguistic corrections.

\section{References}

483 Augusto, L., De Schrijver, A., Vesterdal, L., Smolander, A., Prescott, C., and Ranger., J. 2015.

484 Influences of evergreen gymnosperm and deciduous angiosperm tree species on the

485 functioning of temperate and boreal forests. Biol. Rev. 90: 444-466.

486 Barber, S., Walker, J., and Vasey, E. 1963. Mechanisms for movement of plant nutrients from 487 soil and fertilizer to plant root. J. Agric. Food Chem. 11: 204-207.

488 Bentler, P.M., and Yuan, K.H. 1999. Structural equation modeling with small samples: Test 489 statistics. Multivariate Behavioral Research. 34: 181-197.

490 Bergeron, Y., Gauthier, S., Flannigan, M., and Kafka, V. 2004. Fire regime at the transition 491 between mixedwood and coniferous boreal forest in northwestern Québec. Ecology 85(7): $492 \quad 1916-1932$.

493 Bisbee, K.E., Gower, S.T., Norman J.M., and Nordheim, E.V. 2001. Environmental controls on 494 ground cover species composition and productivity in a boreal black spruce forest. Oecologia 495 129: $261-270$.

496 Blouin J., and Berger, J.P. 2005. Guide de reconnaissance des types écologiques de la région 497 écologique 6a - Plaine du lac Matagami et 6b - Plaine de la baie de Rupert. Ministère des 498 Ressources Naturelles et de la Faune du Québec, Direction des inventaires forestiers, Division 499 de la classification écologique et productivité des stations. Québec, QC.

500 Bonan, G.B., and Shugart H.H. 1989. Environmental factors and ecological processes in boreal 501 forests. Annu. Rev. Ecol. Syst. 20:1-28. 
502 Boudreault, C., Zouaoui, S., Drapeau, P., Bergeron, Y., and Stevenson, S. 2013. Canopy

503 openings created by partial cutting increase growth rates and maintain the cover of three

504 Cladonia species in the Canadian boreal forest. For. Ecol. Manag. 304: 473-481.

505 Brassard, B., Han, W., Chen, Y.H., and Bergeron, Y. 2009. Influence of environmental

506 variability on root dynamics in northern forests. Crit. Rev. Plant Sci. 28(3): 179-197.

507 Brassard, B., Han, W., Chen, Y.H., Bergeron, Y., and Paré. D. 2011. Differences in fine root

508 productivity between mixed-and single-species stands. Funct. Ecol. 25(1): 238-246.

509 Chiapusio, G., Jassey, V.E., Hussain, M.I., and Binet, P. 2013. Evidences of bryophyte

$510 \quad$ allelochemical interactions: The case of Sphagnum. In Allelopathy. Edited by Z.A. Cheema,

511 M. Farooq, and A. Wahid. Springer-Verlag, Berlin. pp. 39-54.

512 Cornelissen, J.H.C., Lang, S.I., Soudzilovskaia, N.A., and During, H.J. 2007. Comparative

513 cryptogam ecology: A review of bryophyte and lichen traits that drive biogeochemistry. Ann.

$514 \quad$ Bot. 99(5): 987-1001.

515 Coxson, D.S., and Marsh, J. 2001. Lichen chronosequences (postfire and postharvest) in

516 lodgepole pine (Pinus contorta) forests of nothern interior British Columbia. Can. J. Bot. 79:

$517 \quad 1449-1464$.

518 DeLuca, T.H., Zackrisson, O., Nilsson, M.C., and Sellstedt, A. 2002. Quantifying nitrogen-

519 fixation in feather moss carpets of boreal forests. Nature 419(6910): 917-920.

520 Fauria, M.M., Helle, T., Niva, A., Posio, H., and Timonen, M. 2008. Removal of the lichen mat

521 by reindeer enhances tree growth in a northern Scots pine forest. Can. J. For. Res. 38(12):

$522 \quad 2981-2993$.

523 Fenton, N.J., and Bergeron, Y. 2006. Facilitative succession in a boreal bryophyte community

524 driven by changes in available moisture and light. J. Veg. Sci. 17(1): 65-76. 
525 Fenton, N.J., Légaré, S., Bergeron, Y., and Paré, D. 2006. Soil oxygen within boreal forests

526 across an age gradient. Can. J. Soil Sci. 56: 1-9.

527 Finér, L., Helmisaari, H.S., Lohmus, K., Majdi, H., Brunner, I., Børja, I., Eldhuset, T., Godbold,

528 D., Grebenc, T., Konôpka, B., Kraigher, H., Möttönen, M.-R., Ohashi, M., Oleksyn, J.,

529 Ostonen, I., Uri, V., and Vanguelova, E. 2007. Variation in fine root biomass of three

$530 \quad$ European tree species: beech (Fagus sylvatica L.), Norway spruce (Picea abies L.Karst.), and

$531 \quad$ Scots pine (Pinus sylvestris L.). Plant Biosyst. 141(3): 394-405.

532 Gower, S.T., McMurtrie R.E., and Murty, D. 1996. Aboveground net primary production decline

$533 \quad$ with stand age: potential causes. Trends Ecol. Evol. 11(9): 378-382.

534 Haughian, S.R., and Burton P.J. 2015. Microhabitat associations of lichens, feathermosses, and

535 vascular plants in a caribou winter range, and their implications for understory development.

$536 \quad$ Botany 93(4): 221-231.

537 Hébert, F., Boucher, J-F., Bernier, P.Y., and Lord, D. 2006. Growth response and water relations

538 of 3-year-old planted black spruce and jack pine seedlings in site prepared lichen woodlands.

539 For. Ecol. Manag. 223: 226-236.

540 Hinsinger, P., Bengough, A.G., Vetterlein, D., and Young, I.M. 2009. Rhizosphere: biophysics,

541 biogeochemistry and ecological relevance. Plant Soil 321(1-2): 117-152.

542 Jasinski, J.P.P., and Payette, S. 2005. The creation of alternative stable states in the southern

543 boreal forest, Quebec, Canada. Ecol. Monogr. 75(4): 561-583.

544 Kalliokoski, T., Pennanen, T., Nygren, P., Sievänen, R., and Helmisaari, H.S. 2010.

545 Belowground interspecific competition in mixed boreal forests: fine root and ectomycorrhiza

546 characteristics along stand developmental stage and soil fertility gradients. Plant Soil 330: 7354789. 
548 Kytöviita, M.M., and Crittenden, P.D. 2007. Growth and nitrogen relations in the mat-forming

549 lichens Stereocaulon paschale and Cladonia stellaris. Annals of Botany. 100: 1537-1545.

550 Kytöviita, M.M., and Stark, S. 2009. No allelopathic effect of the dominant forest-floor lichen

$551 \quad$ Cladonia stellaris on pine seedlings. Funct. Ecol. 23(2): 435-441.

552 Lafleur, B., Paré, D., Fenton, N., and Bergeron, Y. 2010. Do harvest methods and soil type

553 impact the regeneration and growth of black spruce stands in Northwestern Quebec? Can. J.

$554 \quad$ For. Res. 40: 1843-1851.

555 Lafleur, B., Paré, D., Fenton, N.J., and Bergeron, Y. 2011. Growth and nutrition of black spruce

556 seedlings in response to disruption of Pleurozium and Sphagnum moss carpets in boreal

557 forested peatlands. Plant Soil 345: 141-153.

558 Lang, S.I., Cornelissen, J.H.C., Klahn, T., Van Logtestijn, R.S.P., Broekman, R., Schweikert, W.,

559 and Aerts, R. 2009. An experimental comparison of chemical traits and litter decomposition

560 rates in a diverse range of subarctic bryophyte, lichen and vascular plant species. J. Ecol.

$561 \quad 97(5): 886-900$.

562 McCavour, M.J., Paré, D., Messier, C., Thiffault, N., and Thiffault, E. 2014. The role of forest

563 aggregated forest harvest residue in soil fertility, plant growth, and pollination services. Soil

$564 \quad$ Sci. Soc. Am. J. 78: S196-S207.

565 Molnar, K., and Farkas, E. 2010. Current results on biological activities of lichen secondary

566 metabolites: a review. Z. Naturforsch. 65c: 157-173.

567 Nilsson, M.C., and Wardle, D.A. 2005. Understory vegetation as a forest ecosystem driver:

568 Evidence from the northern Swedish boreal forest. Front. Ecol. Environ. 3(8): 421-428.

569 Noguchi, K., Dannoura, M., Jomura, M., Noguchi, M.A., and Matsuura, Y. 2012. High

570 belowground biomass allocation in an upland black spruce (Picea mariana) stand in interior

$571 \quad$ Alaska. Polar Sci. 6: 133-141. 
572 Ohtonen, R., and Väre, H. 1998. Vegetation composition determines microbial activities in a

573 boreal forest soil. Microb. Ecol. 36: 328-335.

574 Payette, S., Bhiry, N., Delwaide, A., and Simard, M. 2000. Origin of the lichen woodland at its

575 southern range limit in eastern Canada: the catastrophic impact of insect defoliators and fire on

576 the spruce-moss forest. Can. J. For. Res. 30(2): 288-305.

577 Persson, H., and Ahlström, K. 2002. Fine-root response to nitrogen supply in nitrogen

578 manipulated Norway spruce catchment areas. For. Ecol. Manag. 168: 29-41.

579 R core team. 2014. R: A language and environment for statistical computing. $\mathrm{R}$ foundation for

$580 \quad$ statistical computing, Vienna, Austria.

581 Sedia, E.G., and Ehrenfeld, J.G. 2003. Lichens and mosses promote alternate stable plant

582 communities in the New Jersey Pinelands. Oikos 100: 447-458.

583 Sedia, E.G., and Ehrenfeld, J.G. 2005. Differential effects of lichens, mosses and grasses on

584 respiration and nitrogen mineralization in soils of the New Jersey Pinelands. Oecologia 144:

$585 \quad 137-147$.

586 Shipley, B. 2002. Cause and correlation in biology: a user's guide to path analysis, structural

587 equations and causal inference. Cambridge University Press, Cambridge, UK.

588 Shirtcliffe, N.J., Pyatt, B.F., Newton, M.I., and McHale, G. 2006. A lichen protected by a super-

589 hydrophobic and breathable structure. J. Plant Physiol. 163: 1193-1197.

590 Simard, M., Lecomte, N., Bergeron, Y., Bernier, P.Y., and Paré, D. 2007. Forest productivity

591 decline caused by successional paludification of boreal soils. Ecol. Appl. 17(6): 1619-1637.

592 Steijlen, I., Nilsson, M-C, and Zackrisson, O. 1995. Seed regeneration of Scots pine in boreal

593 forest stands dominated by lichen and feather moss. Can. J. For. Res. 25: 713-723.

594 Taskinen, O., Ilvesniemi, H., Kuuluvainen, T., and Leinonen, K. 2003. Response of fine roots to 595 an experimental gap in a boreal Picea abies forest. Plant Soil 255(2): 503-512. 
596 Thiffault, N., Fenton, N.J., Munson, A.D., Hébert, F., Fournier, R.A., Valeria, O., Bradley, R.L.,

597 Bergeron, Y., Grondin, P., Paré D., and Joanisse, G. 2013. Managing understory vegetation for 598 maintaining productivity in black spruce forests: A synthesis within a multi-scale research 599 model. Forests 4: 613-631.

600 Turetsky, M.R. 2003. The role of bryophytes in carbon and nitrogen cycling. The Bryologist $601 \quad$ 106(3): 395-409.

602 Ung, C.H., Bernier, P., and Guo, X.J. 2008. Canadian natural biomass equations: new parameter 603 estimates that include British Columbia data. Can. J. For. Res. 38: 1123-1132.

604 Yuan, Z.Y., and Chen, H.Y.H. 2010. Fine root biomass, production, turnover rates, and nutrient 605 contents in boreal forest ecosystems in relation to species, climate, fertility, and stand age:

606 literature review and meta-analyses. Crit. Rev. Plant Sci. 29(4): 204-221.

607 Zadworny, M., McCormack, M.L., Mucha, J., Reich, P.B., and Oleksyn, J. 2016. Scots pine fine 608 roots adjust along a 2000-km latitudinal climatic gradient. New Phytol. 212(2): 389-399. 


\section{Figures and tables}

610 Table 1. Characteristics of the two sampled areas and experimental sites (mean and range).

\begin{tabular}{|c|c|c|}
\hline Forest type & Pine-lichen & Spruce-moss \\
\hline \multicolumn{3}{|c|}{ Sampled areas ( 20 plots nested in 4 sites for each forest type) } \\
\hline \multicolumn{3}{|l|}{ Longitude } \\
\hline Northern limit & $49^{\circ} 25^{\prime} \mathrm{N}$ & $49^{\circ} 45^{\prime} \mathrm{N}$ \\
\hline Southern limit & $49^{\circ} 19^{\prime} \mathrm{N}$ & $49^{\circ} 42^{\prime} \mathrm{N}$ \\
\hline \multicolumn{3}{|l|}{ Latitude } \\
\hline Western limit & $79^{\circ} 15^{\prime} \mathrm{W}$ & $79^{\circ} 18^{\prime} \mathrm{W}$ \\
\hline Eastern limit & $79^{\circ} 11^{\prime} \mathrm{W}$ & $79^{\circ} 16^{\prime} \mathrm{W}$ \\
\hline Drainage & Rapid & Poor \\
\hline Area covered by the study & 2400 ha & 1200 ha \\
\hline Dominant tree species & Pinus banksiana Lamb. & $\begin{array}{l}\text { Picea mariana } \\
\text { [Mill.] B.S.P }\end{array}$ \\
\hline Percentage of dominant species' stems (\%) & $97(77-100)$ & $99(92-100)$ \\
\hline Last disturbance type & Clearcut & Fire \\
\hline Year of the last disturbance & 1980 and 1989 & 1976 \\
\hline Regeneration & Sowing or plantation & Natural \\
\hline Dominant tree age estimated from tree rings (years) & $26.8(17-37)$ & $22.3(18-35)$ \\
\hline Stand density (trees.ha ${ }^{-1}$, all sizes) & $3310(1200-5500)$ & $8800(1600-17000)$ \\
\hline Stand aboveground biomass $\left(\mathrm{t} \cdot \mathrm{ha}^{-1}\right)^{*}$ & $66.0(27.2-104.0)$ & $15.4(1.2-45.9)$ \\
\hline Stand canopy closure $(\%)$ & $61.0(37.0-72.7)$ & $51.5(11.0-86.2)$ \\
\hline \multirow{2}{*}{\multicolumn{3}{|c|}{$\begin{array}{l}\text { Micro-environmental conditions of the understory } \\
\text { from June to September } 2014\end{array}$}} \\
\hline & & \\
\hline Temperature $\left({ }^{\circ} \mathrm{C}\right)$ & $16.1(-3.2-44.5)$ & $16.0(-3.2-43.6)$ \\
\hline Air humidity (\%) & $87.1(12.1-100)$ & $86.8(12.3-100.0)$ \\
\hline Ericaceae aboveground biomass (t.ha $\left.{ }^{-1}\right)$ & $1.65(0.56-3.55)$ & $2.75(0.44-6.72)$ \\
\hline \multicolumn{3}{|l|}{ Ground cover composition $(\%)$} \\
\hline Feather mosses & $45(1-90)$ & $45(10-90)$ \\
\hline Lichens & $45(1-90)$ & $15(0-25)$ \\
\hline Sphagnum spp. & - & $40(0-90)$ \\
\hline Ground living biomass $\left(\text { t.ha }{ }^{-1}\right)^{* *}$ & $11.0(4.4-18.1)$ & $8.1(0.5-28.4)$ \\
\hline Tree fine root biomass $\left(\mathrm{kg} \cdot \mathrm{ha}^{-1}\right)$ & $1380(660-2060)$ & $2810(310-4440)$ \\
\hline \multicolumn{3}{|l|}{ Experimental sites } \\
\hline Longitude & $49^{\circ} 23^{\prime} \mathrm{N}$ & $49^{\circ} 43^{\prime} \mathrm{N}$ \\
\hline
\end{tabular}




\begin{tabular}{|c|c|c|}
\hline Latitude & $79^{\circ} 14^{\prime} \mathrm{W}$ & $79^{\circ} 17^{\prime} \mathrm{W}$ \\
\hline Drainage & Rapid & Poor \\
\hline Area of the experimental site & 2 ha & 4 ha \\
\hline Dominant tree species & Pinus banksiana Lamb. & $\begin{array}{l}\text { Picea mariana } \\
\text { [Mill.] B.S.P }\end{array}$ \\
\hline Percentage of dominant species' stems & $99 \%$ & $92 \%$ \\
\hline Last disturbance type & Clearcut & Fire \\
\hline Year of the last disturbance & 1980 & 1976 \\
\hline Regeneration & Plantation & Natural \\
\hline Dominant tree age estimated from tree rings (years) & $26(24-28)$ & $27(23-30)$ \\
\hline Stand density (trees.ha ${ }^{-1}$, all sizes) & 2570 & 17000 \\
\hline Stand aboveground biomass $\left(\mathrm{t} \cdot \mathrm{ha}^{-1}\right)^{*}$ & 69.0 & 45.9 \\
\hline Stand canopy closure $(\%$, one measure per plot $)$ & $60.2(53.4-66.0)$ & $80.54(78.6-82.0)$ \\
\hline \multicolumn{3}{|l|}{$\begin{array}{l}\text { Micro-environmental conditions of the understory } \\
\text { from June to September } 2014\end{array}$} \\
\hline Temperature $\left({ }^{\circ} \mathrm{C}\right)$ & $16.3(-1.0-40.6)$ & $14.3(-1.0-45.4)$ \\
\hline Air humidity $(\%)$ & $83.3(11.0-100)$ & $96.9(34.4-100.0)$ \\
\hline Initial tree fine root biomass $\left(\mathrm{kg} \cdot \mathrm{ha}^{-1}\right)$ & $1070(520-2110)$ & $1010(300-2760)$ \\
\hline
\end{tabular}

$612 *$ Stand aboveground biomass was estimated from the sum of individual tree biomasses.

613 Individual tree biomasses were estimated based on species-specific biomass equations developed

614 for tree species of Canada (Ung et al. 2008). Model calibration is based on trees ranging from 1.6

615 to $38.4 \mathrm{~cm}$ in diameter at breast height (DBH) for black spruce, and from 2.5 to $48.9 \mathrm{~cm}$ in $\mathrm{DBH}$

616 for pine.

$617 * *$ Ground living biomass corresponds to the living biomass of the moss and/or lichen layer. The

618 whole cryptogam part that did not present leaf/stem blackening or traces of decomposition was

619 considered as living. In the case of Sphagnum spp., which can accumulate a thick layer of

620 undecomposed fibric material, the white parts (unpigmented stems) that were more than $30 \mathrm{~cm}$

621 deep were not considered. 
622 Table 2. Soil characteristics (mean and standard error) of the two sampled areas and links

623 between these characteristics and the degree of canopy closure (Pearson correlation coefficient).

\begin{tabular}{|c|c|c|}
\hline Soil characteristics & Mean $( \pm \mathrm{SE})$ & $\mathbf{r}^{*}$ \\
\hline \multicolumn{3}{|l|}{ Pine-lichen stands } \\
\hline \multicolumn{3}{|l|}{ Mineral soil texture (20 cm deep) } \\
\hline - $\quad$ Proportion of sand $(\%)$ & $87( \pm 5)$ & 0.37 \\
\hline - $\quad$ Proportion of silt $(\%)$ & $8( \pm 6)$ & 0.24 \\
\hline - $\quad$ Proportion of clay $(\%)$ & $5( \pm 2)$ & 0.36 \\
\hline Organic layer depth (m) & $0.12( \pm 0.03)$ & 0.14 \\
\hline \multicolumn{3}{|l|}{ Mineral soil } \\
\hline - Dissolved inorganic nitrogen $\left(\mathrm{mg} \cdot \mathrm{kg}^{-1}\right)$ & $0.86( \pm 0.20)$ & 0.17 \\
\hline - Phosphorus (mg.kg $\left.{ }^{-1}\right)$ & $0.67( \pm 0.29)$ & 0.20 \\
\hline \multicolumn{3}{|l|}{ Spruce-moss stands } \\
\hline Organic layer depth (m) & $0.72( \pm 0.30)$ & 0.10 \\
\hline Water table depth (m) & $0.21( \pm 0.06)$ & 0.00 \\
\hline \multicolumn{3}{|l|}{ Deep organic matter ( $1 \mathrm{~m}$ deep) } \\
\hline - Dissolved inorganic nitrogen $\left(\mathrm{mg} \cdot \mathrm{kg}^{-1}\right)$ & $11.66( \pm 16.23)$ & 0.00 \\
\hline - $\quad$ Phosphorus (mg.kg-1) & $1.90( \pm 1.91)$ & 0.20 \\
\hline
\end{tabular}

624

$625 *$ None of the relationships were significant $(p$-value $>0.1)$. 
626 Table 3. Pearson correlation coefficients between canopy closure, lichen/Sphagnum spp. cover,

627 fine root biomass, stand aboveground biomass and D.I.N. for the two forest types.

\begin{tabular}{lcccc}
\hline & $\begin{array}{c}\text { Lichen/Sphagnum } \\
\text { spp. cover }\end{array}$ & $\begin{array}{c}\text { Fine root } \\
\text { biomass }\end{array}$ & $\begin{array}{c}\text { Stand above- } \\
\text { ground biomass }\end{array}$ & D.I.N. \\
\hline Pine-lichen stands & $\mathbf{0 . 6 6 *}$ & 0.47 & 0.55 & 0.49 \\
Canopy closure & - & -0.33 & -0.56 & -0.40 \\
Lichen cover & - & - & $\mathbf{0 . 6 9 *}$ & 0.15 \\
Fine root biomass & - & - & - & 0.01 \\
Stand aboveground biomass & & & & \\
Spruce-moss stands & $\mathbf{0 . 6 8 *}$ & 0.39 & $\mathbf{0 . 6 2} *$ & 0.00 \\
Canopy closure & - & $-\mathbf{0 . 6 3 *}$ & $\mathbf{- 0 . 7 0 * *}$ & 0.32 \\
Sphagnum spp. cover & - & - & 0.32 & -0.04 \\
Fine root biomass & - & - & - & 0.32 \\
Stand aboveground biomass & & &
\end{tabular}

628

629 Significant relationships (after Bonferroni correction) are given in bold. * $p$-value $<0.005 ; * * p$ -

630 value $<0.001$ 
631 Table 4. Direct effect, indirect effect, non-causal variation and total correlation for path analysis

632 of tree fine root biomass per unit area based on the different hypothesized causal structures.

633 Significant relationships are given in bold.

\begin{tabular}{|c|c|c|c|c|}
\hline Variable & $\begin{array}{c}\text { Direct } \\
\text { Value (Error) }\end{array}$ & Indirect & $\begin{array}{l}\text { Non } \\
\text { causal }\end{array}$ & Total $^{1}$ \\
\hline
\end{tabular}

Pine-lichen forest

Tree fine root biomass (log-transformed)

Stand aboveground biomass

$\mathbf{0 . 7 3 6 ( 0 . 1 7 3 ) * * *} \quad-0.031 \quad 0 \quad 0.688$

Lichen cover

$0.085(0.173)$

$0 \quad-0.267$

$-0.327$

Canopy closure

0

$-0.056$

0.407

0.469

\section{Spruce-moss forest}

Tree fine root biomass (model 1)

Stand aboveground biomass

$\begin{array}{llll}-0.253(0.189) & 0.307 & 0 & 0.319 \\ \mathbf{- ~ 0 . 7 8 6 ( 0 . 1 8 9 )} * * * & 0 & 0.099 & -0.602 \\ 0 & 0.494 & -0.157 & 0.390\end{array}$

Sphagnum spp. moss cover

Canopy closure

0.494

.390

Tree fine root biomass (model 2)

Stand aboveground biomass

$\begin{array}{llll}-0.226(0.254) & 0 & 0.546 & 0.319 \\ \mathbf{- ~ 0 . 7 5 0 ~ ( 0 . 2 5 3 ) * *} & 0.165 & 0 & -0.633 \\ 0 & 0 & 0.258 & 0.390\end{array}$

Sphagnum spp. moss cover

Canopy closure

0

0.258

634

$635 * * p$-value $<0.01 ; * * * p$-value $<0.001$.

$636{ }^{1}$ Total value represents the Pearson correlation coefficient (r). 
637 Table 5. Treatment effect on tree fine root biomass and soil characteristics for the two forest 638 types. Significant $p$-values are given in bold.

\begin{tabular}{|c|c|c|c|c|c|c|}
\hline \multirow{3}{*}{ Final tree fine root biomass $\left(\mathrm{kg} . \mathrm{ha}^{-1}\right)$} & \multicolumn{3}{|c|}{ Pine-lichen } & \multicolumn{3}{|c|}{ Spruce-moss } \\
\hline & \multirow[t]{2}{*}{$\mathrm{t}$} & \multirow[t]{2}{*}{$p$-value } & \multirow[t]{2}{*}{$\mathrm{R}^{2}$} & \multirow[t]{2}{*}{$\mathrm{t}$} & \multirow[t]{2}{*}{$p$-value } & \multirow[t]{2}{*}{$\mathrm{R}^{2}$} \\
\hline & & & & & & \\
\hline Lichen/Sphagnum spp. removal (1) & 2.05 & 0.0483 & 0.04 & 0.15 & 0.8816 & 0.06 \\
\hline Fertilization (2) & 1.29 & 0.2049 & & 1.99 & 0.0550 & \\
\hline Shade (3) & 0.35 & 0.7315 & & -0.21 & 0.8356 & \\
\hline Interaction $(1) *(2)$ & -1.53 & 0.1368 & & - & - & \\
\hline Interaction $(1) *(3)$ & -0.41 & 0.6829 & & - & - & \\
\hline \multicolumn{7}{|l|}{ Dissolved Inorganic Nitrogen $\left(\mathrm{mg} \cdot \mathrm{kg}^{-1}\right)$} \\
\hline Lichen/Sphagnum spp. removal (1) & 0.12 & 0.9065 & 0.58 & -0.85 & 0.4044 & 0.66 \\
\hline Fertilization (2) & 4.47 & 0.0001 & & 3.57 & 0.0011 & \\
\hline Shade (3) & -1.26 & 0.2165 & & -0.77 & 0.4496 & \\
\hline Interaction $(1) *(2)$ & -2.16 & 0.0383 & & 2.49 & 0.0183 & \\
\hline Interaction $(1) *(3)$ & 1.75 & 0.0898 & & 1.91 & 0.0651 & \\
\hline \multicolumn{7}{|l|}{ Phosphorus (mg.kg $\left.{ }^{-1}\right)$} \\
\hline Lichen/Sphagnum spp. removal & -1.09 & 0.2830 & 0.04 & 0.72 & 0.4746 & 0.30 \\
\hline Fertilization & 1.26 & 0.2170 & & 4.22 & 0.0002 & \\
\hline Shade & -0.50 & 0.6230 & & 1.32 & 0.1972 & \\
\hline \multicolumn{7}{|l|}{ Potassium (cmol.kg ${ }^{-1}$ ) } \\
\hline Lichen/Sphagnum spp. removal (1) & 2.51 & 0.0178 & 0.26 & -0.18 & 0.8560 & 0.19 \\
\hline Fertilization (2) & 2.50 & 0.0180 & & 2.87 & 0.0071 & \\
\hline Shade (3) & 1.81 & 0.0803 & & -0.32 & 0.7486 & \\
\hline Interaction $(1) *(2)$ & -3.65 & 0.0010 & & - & - & \\
\hline $\operatorname{Interaction}(1) *(3)$ & -3.12 & 0.0040 & & - & - & \\
\hline \multicolumn{7}{|l|}{ Sum of major base cations $\left(\mathrm{cmol}^{\mathrm{kg}} \mathrm{kg}^{-1}\right)$} \\
\hline Lichen/Sphagnum spp. removal (1) & 2.45 & 0.0204 & 0.24 & -0.34 & 0.7335 & 0.13 \\
\hline Fertilization (2) & 2.47 & 0.0193 & & -0.10 & 0.9204 & \\
\hline Shade (3) & 1.07 & 0.2914 & & -0.77 & 0.4498 & \\
\hline Interaction $(1) *(2)$ & -3.47 & 0.0016 & & 1.41 & 0.1690 & \\
\hline Interaction $(1) *(3)$ & -2.29 & 0.0290 & & 2.03 & 0.0511 & \\
\hline
\end{tabular}


640

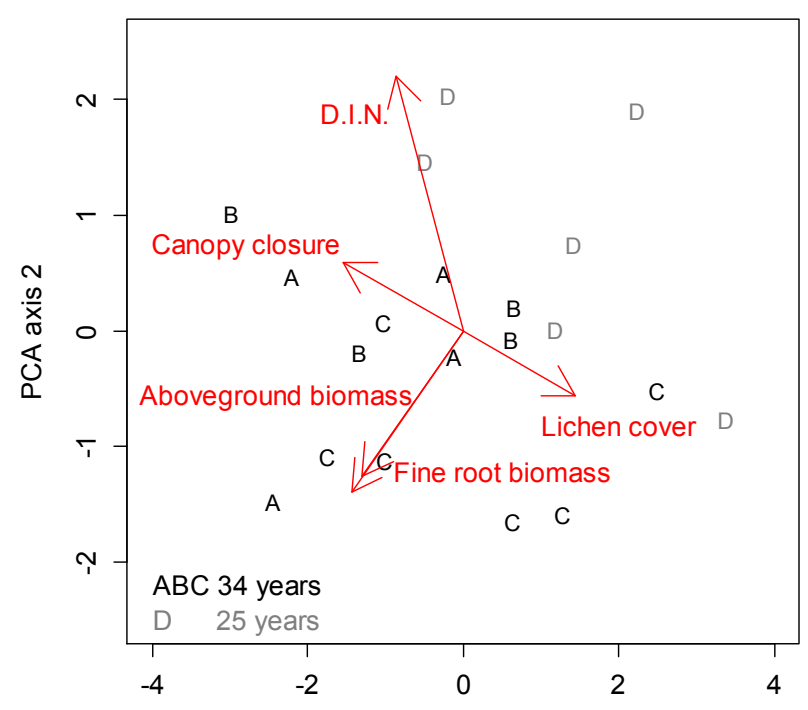

a.

PCA axis 1

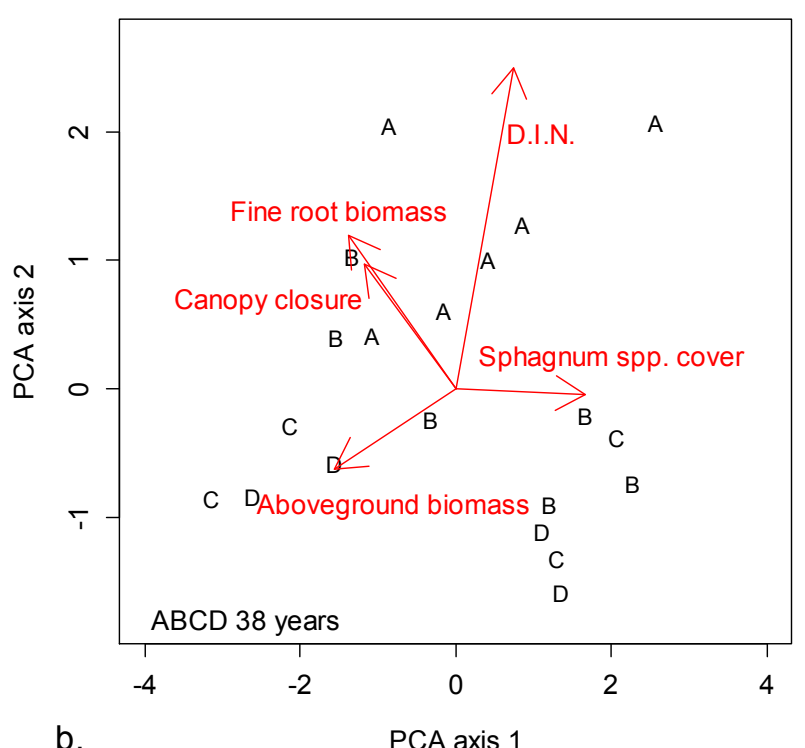

641

642 Fig. 1. Scores of the 20 plots along axes 1 and 2 of the Principal Component Analysis based on

643 six target variables. a) Pine-lichen stands; b) Spruce-moss stands. Each plot (20 per forest type) is

644 represented by the letter of the matching site (A, B, C or D) in the colour corresponding to stand

645 age (see figure for legend). For each variable, the direction of variation is indicated by an arrow. 


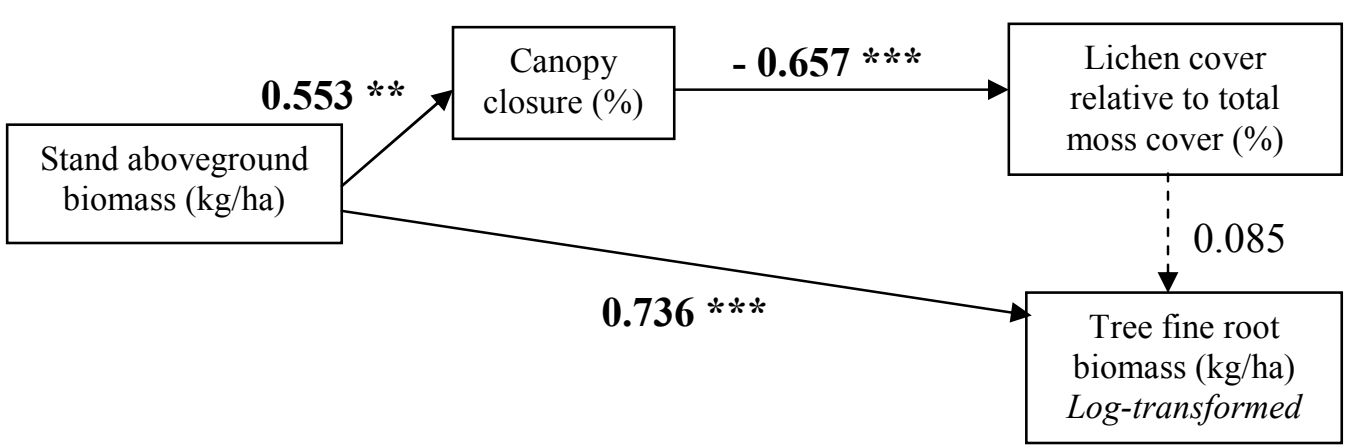

a.

b.
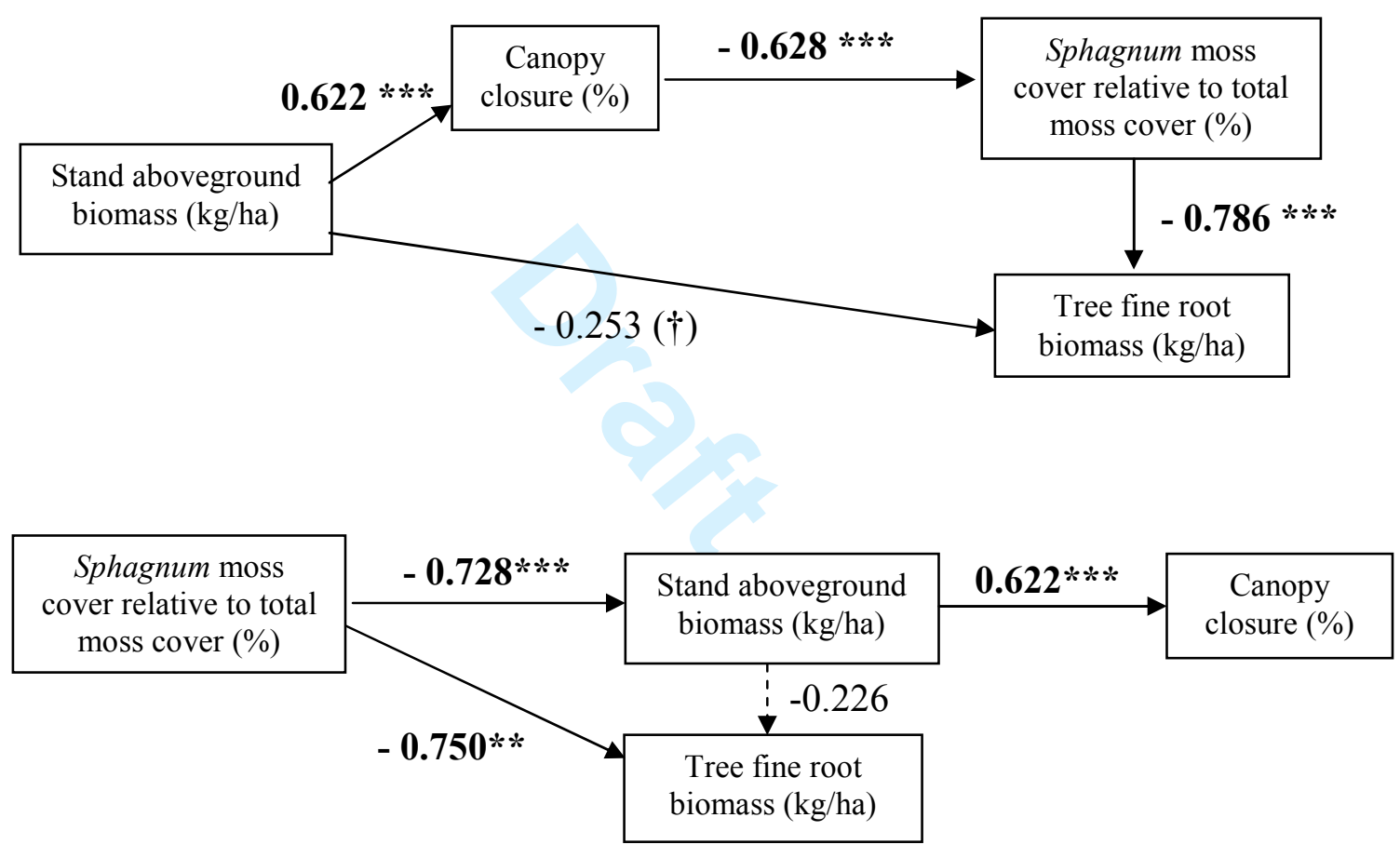

664 Fig. 2. Schematic representation of three different hypothesized causal structures including stand

665 aboveground biomass, canopy closure, ground cover composition and tree fine root biomass. a)

666 Pine-lichen stands $(\chi=2.91 ; \mathrm{df}=2 ; p$-value $=0.23$; scaling correction factor for the Yuan-

667 Bentler correction $=0.801)$; b) Spruce-moss stands, model $1(\chi=11.48$; $\mathrm{df}=2 ; p$-value $<0.01$;

668 scaling correction factor for the Yuan-Bentler correction $=0.65)$; c) Spruce-moss stands, model 2 
$669(\chi=2.59 ; \mathrm{df}=1 ; p$-value $=0.11 ;$ scaling correction factor for the Yuan-Bentler correction $=$ $670 \quad 0.87)$.

671 Significant correlations are indicated in bold (** $p$-value $<0.01$; *** $p$-value $<0.001)$. As

672 recommended by Shipley (2002) for small size samples, possible edges characterized by a

673 significant level lower than $0.2(\dagger)$ are also represented as solid lines. 

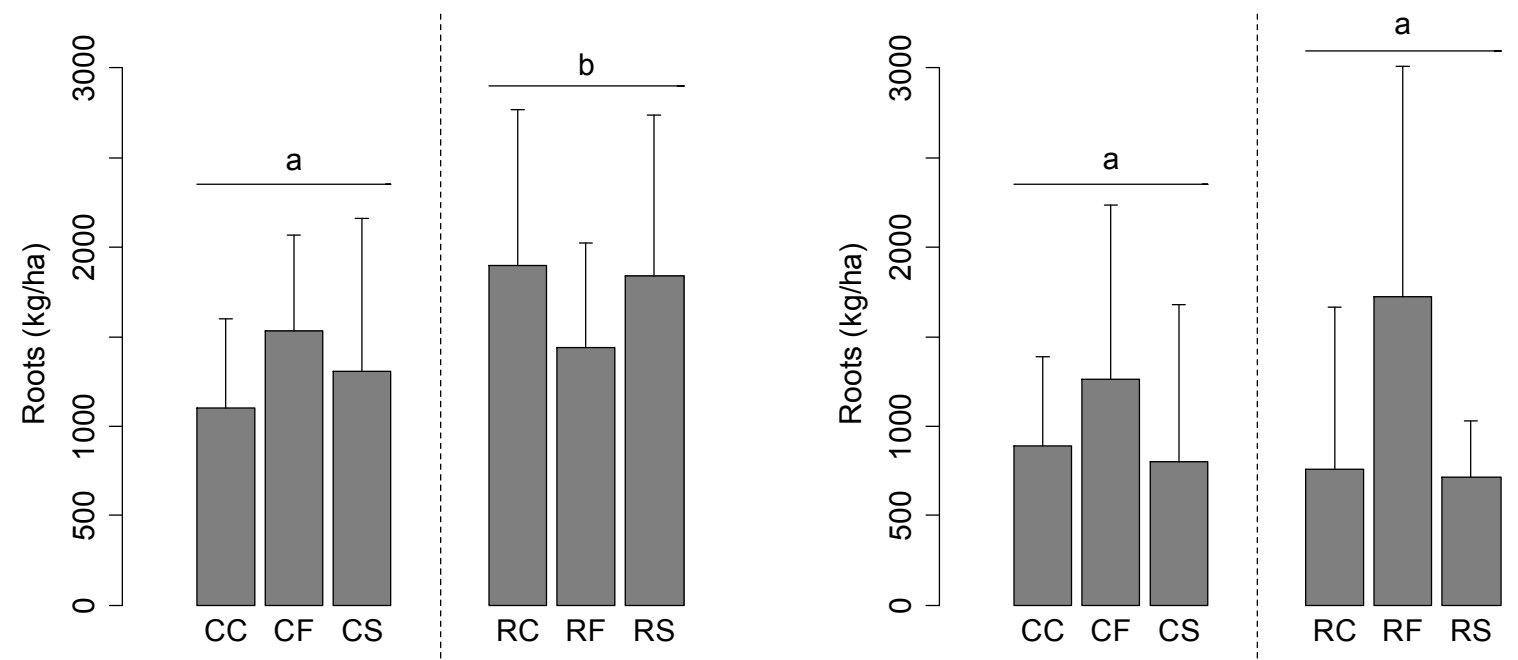

674

a.

b.

675 Fig. 3. Treatment effect on tree fine root biomass for the two forest types. a) Pine-lichen stands;

676 b) Spruce-moss stands. CC: Control x Control; CF: Control x Fertilization; CS: Control x Shade;

677 RC: Removal x Control; RF: Removal x Fertilization; RS: Removal x Shade. Significant

678 differences between ground cover treatments are represented by different letters. Vertical bars

679 represent standard deviations. 


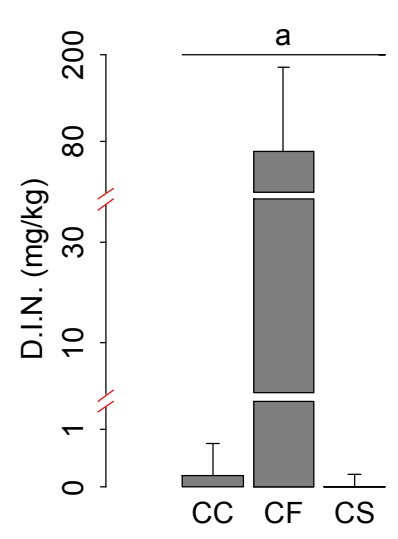

a.

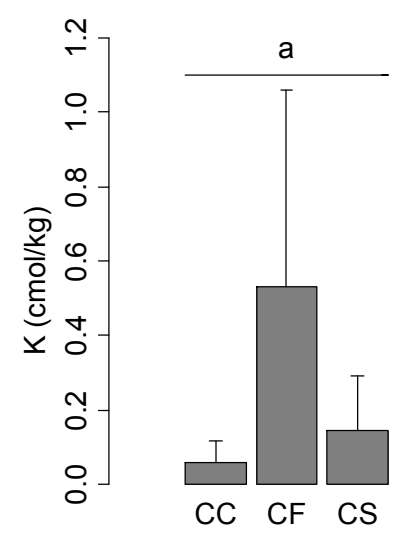

680

681 Fig. 4. Treatment effect on soil characteristics in the pine-lichen forest. a) Dissolved Inorganic

682 Nitrogen (D.I.N.); b) Phosphorus (P); c) Potassium (K); d) Base cations. CC: Control x Control;

683 CF: Control x Fertilization; CS: Control x Shade; RC: Removal x Control; RF: Removal x

684 Fertilization; RS: Removal x Shade. Significant differences between ground cover treatments are

685 represented by different letters. Vertical bars represent standard deviations. 

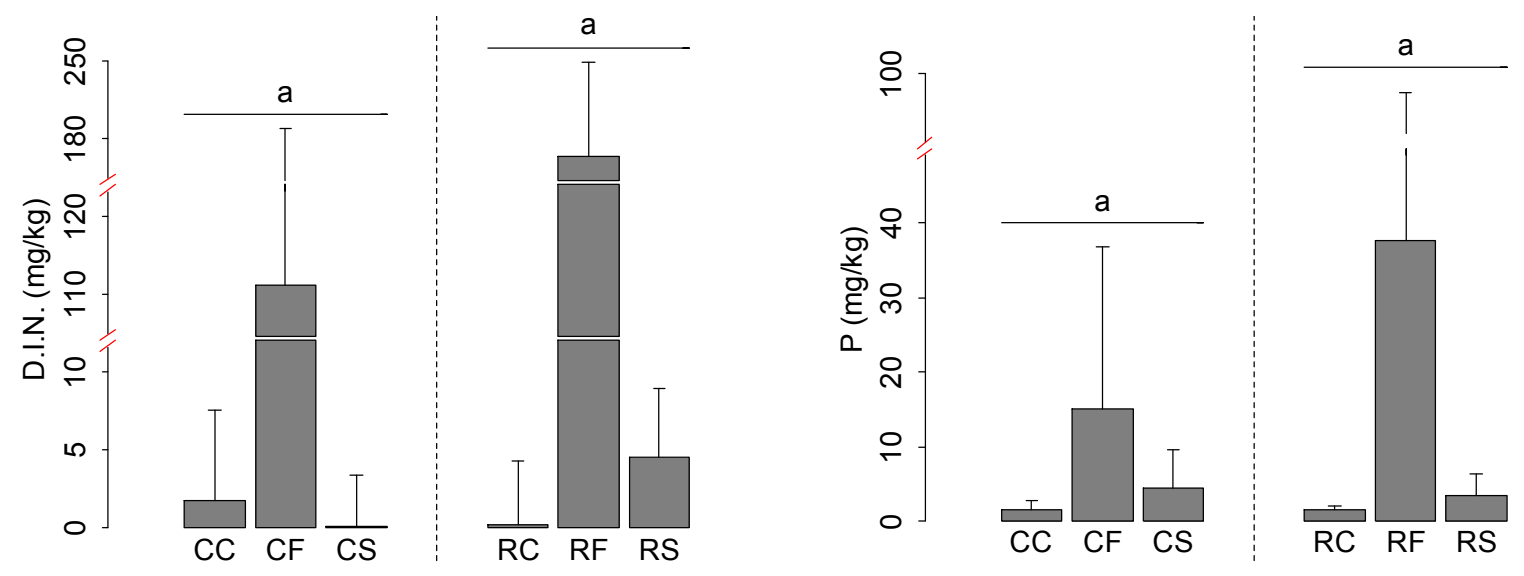

a.
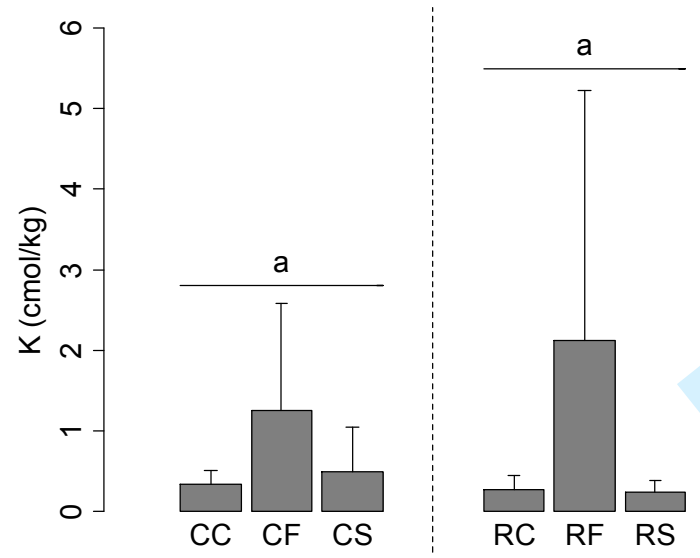

b
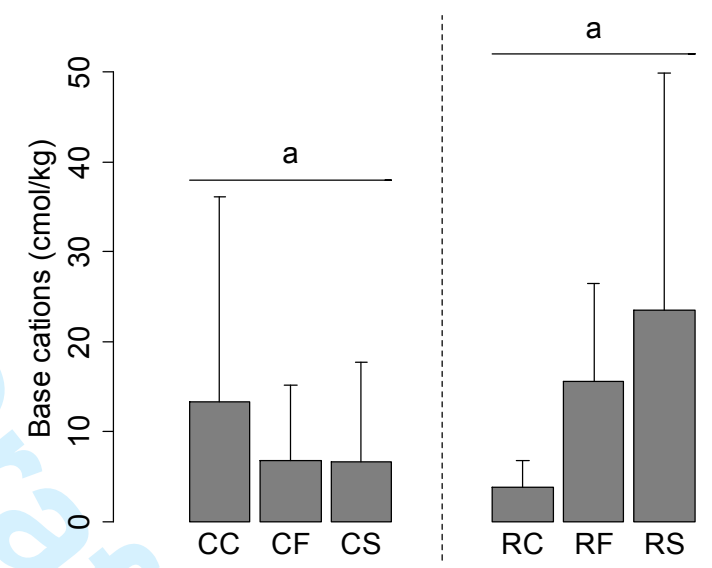

686 c.

687 Fig. 5. Treatment effect on soil characteristics in the spruce-moss forest. a) Dissolved Inorganic 688 Nitrogen (D.I.N.); b) Phosphorus (P); c) Potassium (K); d) Base cations. CC: Control x Control; 689 CF: Control x Fertilization; CS: Control x Shade; RC: Removal x Control; RF: Removal x

690 Fertilization; RS: Removal x Shade. Significant differences between ground cover treatments are 691 represented by different letters. Vertical bars represent standard deviations. 